DOI: https://doi.org/10.34069/AI/2021.38.02.4

\title{
Ukrainian Intellectual Drama of the 2000s
}

\section{Українська інтелектуальна драма 2000-х років}

Received: February 15, 2021

\begin{abstract}
In spite of the presence in contemporary scientific works, the terms 'intellectual drama' and 'intellectual theater' have blurred boundaries. The aim of the article is to identify productive genres and methods of intellectualization in Ukrainian drama of the 2000s. The category of genre was taken as the basis for material structuring. Genre analysis is combined with a poetics analysis of a literary work and an analysis of theatrical techniques that promote intellectualization. Regardless of the genre determined by a writer for a work, no matter what generation an author identifies himself with, the play-writers are common in the importance of keeping eye on the today's world. But this does not condition the realism of the content of scripts or when performed on the stage. The study confirms that parable drama, intellectual and philosophical drama, biographical drama, drama of the absurd belong to the actual genres of intellectual drama. The synthesis of styles, arts, and acting provocations is dominated on the Ukrainian stage of the 2000s. Escalation of conflict is emphasized by means of special stage features (a moving platform, specific color or sound, etc.). The conflict of selfidentification is among the variety of inner conflicts presented in plays.
\end{abstract}

Abstract

Key Words: intellectual drama; intellectualization; drama genres; intellectual theater; Ukrainian literature.
Accepted: March 30, 2021

\author{
Written by: \\ Tetiana Virchenko \\ https://orcid.org/0000-0001-7953-2285 \\ Roman Kozlov \\ https://orcid.org/0000-0001-5912-9106
}

\begin{abstract}
Анотація
Незважаючи на використання в сучасних наукових працях, змістові межі термінів «інтелектуальна драма» та «інтелектуальний театр» доволі розмиті. Метою статті $\epsilon$ виявлення продуктивних жанрів і прийомів інтелектуалізації української драматургії 2000х років. В основу структурування матеріалу покладено категорію жанру. Жанровий аналіз поєднано 3 аналізом поетики літературного твору i аналізом театральних прийомів, які сприяють інтелектуалізації. Незалежно від визначеного письменником жанру твору, незалежно від того, з яким поколінням автор себе ототожнює, драматурги мають спільну установку на відтворення проблем сучасного світу. Але це не приводить до реалістичного змісту п’єс чи їхніх театральних постановок. Дослідження дає підставу стверджувати, що актуальними жанрами, де діє інтелектуалізація, $\epsilon$ драма-притча, інтелектуально-філософська драма, біографічна драма, драма абсурду. Синтез стилів, видів мистецтва, мистецькі провокації домінують на українській сцені 2000-х років. Розвиток конфлікту підкреслюється за допомогою особливих сценічних засобів (рухомої платформи, специфічного кольору чи звуку тощо). Серед різноманіття представлених у п’єсах внутрішніх конфліктів помітним $€$ конфлікт самоідентифікації.
\end{abstract}

Ключові слова: інтелектуальна драма; інтелектуалізація; драматургічні жанри; інтелектуальний театр, українська література.

\footnotetext{
${ }^{7}$ Dr. in Philology, Borys Grinchenko Kyiv University, Ukraine.

${ }^{8}$ Dr. in Philology, Borys Grinchenko Kyiv University, Ukraine.
} 


\section{Introduction}

Following the overview of contemporary drama study publications, it seems that intellectual drama (along with intellectual theater) is not considered to be one of the topical theoretical issues. Though, it is worth pointing out that this term is used to describe a certain reality whose boundaries are not explicitly defined.

Although this term cannot be found in the "Dictionary of the Theatre: Terms, Concepts, and Analysis" (Pavis, 1998), it often appears in the overview of the history of European drama and theater of the second half of the 19th - 20th centuries. It is used to refer to quite different phenomena: the naturalistic theater of Émile Zola, realistic and mythological plays of Henrik Ibsen and Gerhart Hauptmann, the drama of ideas by Bernard Shaw, the epic theatre of Bertolt Brecht, and even the theatre of the absurd (Williams, 1920; Brockett and Hildy, 2014). This diversity can draw the curtain on interesting theoretical issue: what is actually intellectual drama?

In the history of Ukrainian drama, in most cases the names of Lesia Ukrainka and Volodymyr Vynnychenko are mentioned among the intellectual drama representatives. Interestingly, the theatrical histories of the works of these authors are quite different. Lesia Ukrainka's plays almost have not been staged, and the stage directors always experienced difficulties with them. Instead, Vynnychenko was one of the most popular authors in the Ukrainian theaters in the early 20th century.

Recently, in the publications on the contemporary Ukrainian drama and theater, some play-writers and stage directors have increasingly attributed their works to the intellectual theater. Why has it been occuring? There is a temptation to answer this question with a simple binary opposition and contrapose the intelligent drama to the entertaining theater. However, the historical trail of this concept is much more complex and contradictory. Therefore, it should be studied in more details what the contemporary Ukrainian play-writers and stage directors have in mind when they refer their works to intellectual ones.

However, there is another, somewhat nonobvious question. What exactly caused such attention to the intellectualization of theater? The answer is to be found that historically authors and audience in European countries and in Ukraine were interested in the intelligent drama. We dare to suggest that the key aspect here is the change of the ideological emphasis in public life. This refers to the spread of modern ideologies in the late 19th century; the crisis of democratic ideas after the First World War; aggravation of the ideological struggle before and during the Second World War; humanities crisis during the postwar and Cold War period. Paradoxically, the dominant ideologies that have defined the life in Europe and of the mankind over the last one and a half century are very close and, at the same time, strongly opposed. (Yermolenko, 2018). And this, in particular, dialectically makes it possible to confront them in artistic conflict.

Contemporary Ukraine is experiencing another ideological crisis. Gaining of independence almost 30 years ago has only partially transformed the ideological map of Ukraine. Over the years, there have been gradual evolutionary changes in the minds of citizens, and revolutionary shifts (in particular in 2004 and 2013-2014), and, unfortunately, reactionary backtracks. Armed aggression and the occupation of part of the Ukrainian territories have again raised issues connected to national ideology and Ukrainians' identity awareness.

It was only in the spring of 2015 that the Ukrainian parliament passed the laws that approved the country's decommunization policy. However, the implementation of these laws is still being resisted in specific cities and towns. That all but erodes the national identity of Ukrainians.

The artists in the contemporary Ukrainian theater world feel their involvement in the education of Ukrainian citizens, so the matters of ideology, values, their representation and opposition on the Ukrainian stage are relevant. Perhaps, that is why the topic of intelligent Ukrainian theater has increasingly been raised.

However, a reasonable answer to this question can be given only after determining what intellectual theater is in the context of the development of the European theater and ideology, and what place this concept takes in the trends of the contemporary Ukrainian drama. Such a scheme will determine the logic of the study. The theoretical observations based on structuralistic opposition, as well as critical and journalistic observations of the contemporary Ukrainian drama and theater figures will be brought to our attention. 
To structure the material, one should refer to a somewhat established scientific classification construct which can be a genre system in terms of repertoire, critical and scientific practice. Thus, we distinguish the characteristics of intellectual drama from the established repertoire and scientific genre definitions and determine which genres are productive for intellectualization in the history of European theater and in contemporary Ukrainian theatrical discourse. We expect that solving these tasks will enable to get an insight into the trends and potential of the contemporary Ukrainian intellectual drama development.

\section{Theoretical Framework}

In the history of literature, it has occurred more than once that for defining a certain phenomenon a rather random term is brought into use. Eventually, these sort of terms happen to get their new life irrespective of who coined them. And sometimes they spread out even against an author's will, e.g. Julia Kristeva's intertextuality or Bertolt Brecht's epic (instead of dialectical) theater.

At the turn of the 19th and 20th centuries the term intellectual drama was quite common in theaterrelated environment. For example, the letter to The New York Times' editor signed by James Platt White from Buffalo published on February 1,1903 is the one that has drawn our attention. In the letter "The pandarism of the intellectual drama", an indignant reporter is concerned with the moral aspects of staging for English audience of "The Power of Darkness" and "Resurrection" by Count Lev Tolstoy. Here with the reporter does not need to prove that staging scenes from the novel about the life of a provincial prostitute are referred to the intellectual drama. He finds it sufficient enough that the work touches a serious social problem of all time (White, 1903).

H. Williams applies a similar logic in a review of modern English literature (1920). In the "Literary and intellectual drama in England" chapter, the author argues that the development of this type of plays was influenced by Henrik Ibsen:

Mr Galsworthy, Mr Bernard Shaw, Mr Granville Barker, and St John Hankin are typical examples of the influence of Ibsen, working itself out toward a drama of modern life which shall avowedly treat of those social and economic questions which vex the world. (Williams, 1920: 211)
However, intellectual drama is quite an independent phenomenon, which should not be correlated with the creative peculiarities of an individual play-writer. In other words, the essence of intellectual drama does not mean following suit of Henrik Ibsen:

The enduring greatness of Ibsen lies not in his stagecraft, not in his bald dialogue, not in his didactic propensity, but in that deep-founded current of poetry and mysticism, which, even in his prose dramas of social life, he has been unable altogether to obscure. As a poet, unhappily, Ibsen has made little impression upon contemporary drama. He has been understood as an intellectualist, a prophet, a naturalistic painter of life, and it is thus conceived that he has been a dominant force in moulding the younger dramatists of the day. (Williams, 1920: 195-196)

The distinctive features of what $\mathrm{H}$. Williams characterizes as intellectual drama can be distinguished based on his characteristics of the works of some play-writers:

Thus it follows that Mr Shaw sees life and portrays it in his drama through the mists of Fabian theory and argument. His temper is matter-of-fact: his emotions, and he is not without them, are cowed by an aggressive intellect. There is no room in his world for that kindliness, simple affection, bright-eyed or tearful sentiment which do most to redeem life and save human existence from the intolerable. (Williams, 1920: 201-202)

The importance of Mr Galsworthy's work in modern drama does not lie in its artistic power, but in its moral implication and the ethical force of the author. That 'The Moral' is the keynote of all drama' is the chief article of his faith; and by this he means neither a moral which is a propitiatory dramatisation of a code approved by nine-tenths of the audience, nor the code by which the author himself lives, but a moral without any immediate practical purpose, left to the deduction of the individual from a faithful and undistorted presentation of things as they are for their own sake - in a word, the ethical method of Shakespeare. (Williams, 1920: 209).

It is very interesting to trace which prospects of the development of intellectual drama this researcher observes as a contemporary of its crisis. It should also be remembered that the crisis of "realistic" theater was caused not only by the exhaustion of themes, but also by the horrors of World War I: 
But, even before the war, there were signs that the vein of the social and economic problem play had been overworked. Younger playwrights, even those who, for want of a better term, are to be named 'realists,' began to abandon the pose of the demagogue and social reformer, to embrace again in drama the unchangeable problems of the individual life - work and ease, hunger and fullness, the relationship of man and woman in the simplest terms, of the old and the young, friendship, love and hate. In these writers the influence of Ibsen was not absent, but the impress of other ideals appears, including that of the Irish school of dramatists. (Williams, 1920: 212)

The tendency predicted by $\mathrm{H}$. Williams became true. After the end of the Great War the theater didacticism lost its value, and it turned out that unrealistic forms of theater could also be the carriers of intellectualism (Brockett and Hildy, 2014: 359-400). Thus, some important features of intellectual drama were outlined. First of all, it is the presence of conflict in the mind of the hero, who is in a search of their own essence in a state of self-reflection. From a thematic point of view, moral and ethical aspects are dominant in such plays; they are solved not through situational specifics, but rather in a philosophical way.

It was not only by chance that there is the possibility of the scenes where ordinary men and women with their trivial problems can be carriers of universal human philosophical concepts. This process is associated with the formation of new ideologies:

For the traditional aristocratic interpretation, the one who does not work and lazies around has a higher social position than the one who has to work. For the new and modern understanding (and it is common for racism, nazism and marxism), the aristocratic mass is a group of people who can perform better than others. This very group is a superior race or 'progressive' class of people. (Yermolenko, 2018: 238-239)

At the same time, such an upheaval was not the only thing that fin de siècle brought along. It was a time of total denial of the established ways and methods. And the art did not stay aside. The intellectual drama that was developed at the time on the basis of the perfect theater technique had to move ahead according to the ideologies development and cover new areas of artistic expression:

The avant-garde <...> will take this experience to the full and turn it into a mass intellectual movement at least within the minorities where the main aesthetic value is the desire to perform as never before, to do the unprecedented, to speak the unheard, to draw the unseen and to express the unspoked. (Yermolenko, 2018: 246)

Moreover, as early as Henrik Ibsen's time, the intellectual theater was not limited only to realistic displaying of the reality. Preserving the main themes and conflicts in his works, Henrik Ibsen was drawing near symbolism. Yet with that, credibility still remained an important feature of his works in many scopes, i.e., in the scenarios, in the mises-en-scènes and in the psychological motivation behind the characters' actions (Brockett and Hildy, 2014: 362-363). The similar ideas refer to the works of Bernard Shaw:

Although Shaw is related to the realistic movement through his concern for ideas and social problems, he differs markedly from most of the writers of this school. While acknowledging the importance of heredity and environment, Shaw always implies that human beings have freedom of choice. Furthermore, although his characters often speak in dialect, they are always articulate and seldom follow closely the patterns of everyday speech. Shaw was not objective, for he chose his characters and invented his stories to illustrate a point of view. (Brockett and Hildy, 2014: 369)

It can be argued that the intellectual drama established only after the theatrical technique had reached its excellence. This was possible due to the penetration of the scientific ideas into the theater, i.e., positivism. The dominance of positivism in all the domains of human knowledge has for the most part shaped the main ideologies according to the Auguste Comte program: "Their object is, to constitute at length a real Providence, in all departments - moral, intellectual, and material" (1858: 1). "Constituting the real Providence" is the formation of artistic images that seem true. That encompasses realism, and plausibility, and the causal motivating force of the plots. It is no mere chance that well-made play became the dominant form of European theater in the second half of the 19 th century.

In a 'classical' dramaturgy, where space, time, actions help us segment unambiguously the show according to its signifiers and signifieds, this show will seem to us readable, we will forget about the deciphering of the signs, with the risk however that the mise en scène results in a too obvious, redundant, boring 'mise en signes' (putting into signs). (Pavis, 2012: 39) 
It is the well-made play that made possible the development of the intellectual drama as a kind of superstructure. Resultantly, it highlights the meaningful content of utterances, rather than the means of stage effects creation. However, this situation requires certain conditions, under which not only the system of theatrical cues should be developed, but also the audience should acquire the competence to interpret the established theatrical cues. In addition, the audience should have been sated with 'entertaining' performances.

The Ukrainian theater seems to dwell in this position. Due to the improvement of the economic situation, performances no more elite art, but rather mass events, bringing forth a sufficient number of experienced audiences. On the other hand, there are enough other forms of leisure and entertainment that promote the intellectualization of Ukrainian theater.

At the beginning of the 20th century, intellectual theater already existed as a drama of ideas and a comedy of ideas (Bernard Shaw, Oscar Wilde, Jean-Paul Sartre). In the middle of the century, such diversity was confirmed by intellectualization of the epic theater and the theater of the absurd (Esslin, 2001: 19).

Thus, we can make a conclusion that the intellectual drama is a certain sub-genre or crossgenre superstructure which brings in the play certain features enhancing its content and stimulating the viewer to decode the ideas behind a story line. Historically, the most productive for intellectualization are the social / biographical drama and comedy, the parable, the fairy tale, and the absurdist play.

\section{Methodology}

The aim of this study is to identify productive genres and methods of intellectualization in Ukrainian drama of the 2000s. The plays of the most outspoken supporters of the intellectualization movement among Ukrainian playwrights of the early 21 st century have been selected for this purpose. Oleksandr Chirkov and Hryhoriy Shton belong to the so-called "professors-playwrights" because they have the corresponding scientific degrees. Sashko Ushkalov, Artem Vyshnevskyi are authors-fans of the theater of the absurd. The analysis also covers productions of works by other playwrights, we selected those ones, in which the most noticeable signs of intellectualization.
The severity of genre features of plays and the main changes in them are analyzed. Genre analysis made it possible to identify those genres that are most susceptible to intellectualization. At the same time, the analysis of poetics was used to get an idea of the main methods of intellectualization. We paid attention to both literary and theatrical techniques. As a result, it became clear why the play, without clear signs of intellectuality, acquires them during staging in the theater.

\section{Results and Discussion}

Intellectualization of Productive Genres in Ukrainian Drama of the 2000s.

Among the genres which allow the intellectual drama to realize should be mentioned the dramaparable. In the contemporary literary process, Olexander Chyrkov is the one who gives preference to the creation of drama-parables.

The titles of plays are what attracts the attention by being clear and concise. Furthermore, they are focused on the person and the search for the fabric of being ("“The Eternal' and the Mortal", "Where is the Truth?"), concentrated on fluidity of time ("Assumption of Times"), on the spiritual word and its ability to awaken ("Session of Vivid Writing"). They tune a reader into a philosophical mode. The philosophical tone of content speaks for the inevitability of the author's dialogue with the recipient. The latter gives rise to the macro idea of a play.

The content of the drama-parable must be characterized by the use of a traditional "eternal" plot. That can be explored in the play "The Damned". The author's designation of the setting ("Action happens at all times, everywhere and nowhere") emphasizes the eternity of the depicted. The character of the Mentor is fundamentally important. He takes his trade in carnest, deeply thinking about how and what to teach. Such an approach will stimulate the Disciple's thinking. That is why the Disciple wrote a parable whose objective was to display the Mentor's mission which is not to pass on "ready-made" knowledge but teach how to learn.

O. Chyrkov's drama-parables are full of intertextual inclusions. And Hamlet's "To be or not to be?" expresses how important it is to find the answer to the question "To live with love or not to live without?" He skillfully raises the questions that need to be answered: "Is the truth eternal?", "What is sin?", "Is the essence of good 
and evil universal for all people?" (2019). Thus, the playwright holds the reader's attention.

The Mentor-Disciple dialogue is the search for the answer to the question "Who the human is?" The play-writer believes that the essence of the human comes not with the birth, but with acquired ability to love. The Mentor acts as an existentialist; for him it is important that people follow their own personality rather than herd mentality.

The intertextual inclusions, i. e. the themes of the poetry by Omar Khayyam, Sappho, and Alcaeus, are also evident in the play "The Eternal and the Mortal" and are used for revealing the longing for love expression. Furthermore, the play is interesting in terms of the author's striving to develop the traditions of the ancient stage by rethinking the content potential for the space structuring. The play's content is full of comprehension of war, human responsibility, and awareness of the life's mission.

The inner world of the characters is revealed by O. Chyrkov through their actions. The playwriter shows the generalized characters of two different types of people sticking to different values. Their confrontation underpins the basis of artistic conflict. While the wealth is the most important for the Eternal ("We are eternal because there is 'something' in our purses"), for the Mortal it is the creation of harmony in the soul and building relationships on the basis of love ("Love lives only in the soul!") (Chyrkov, 2019).

In the epilogue, the conflict between the Eternal and the Mortal is escalated as, due to the power of word, people do not wish to remain a silent crowd. In general, the conflict aggravation and the plot dynamic are achieved by laconic and emotional cues. To emphasise the sharpening of the conflict, the dramatist implements the movement of the stage platform.

In the play "The Eternal and the Mortal", the author raises an eternal philosophical issue of the purpose of art. Seeking for answers to questions about the strength of words, personality goals, and ways to preserve one's soul, the play-writer comes to the only possible conclusion: "The uniqueness of art is beyond the control of the Eternal, since only the art is eternal" (Chyrkov, 2019). In the play "Session of Vivid Writing," O. Chyrkov continues to develop the subject of art. As early as in the first dialogue, the playwriter shows how fine is the line between the true art and the kitsch, how difficult and important it is to convey the idea "The thought is the garment of the feeling!" (2019)

In each of O. Chyrkov's plays one can notice a distinct attention to being beyond the time. The title of the play "Assumption of Times" makes one think about the movement of time as well as its exhaustion before the last frontier of human life. The symbol of measured and eternal movement of time in the play can come the image of the clock. The play-writer opts a sand-glass and flips it on one side. Thus, he manages to emphasize the finiteness of life flow, embedded in the title: "Life in general is woven from the infinity of losses" (Chyrkov, 2019). According to the author, the human always resorts to the memories of the past when going through a breakdown before the next growth.

For O. Chyrkov it is important to create a person of integrity, and therefore the human who has found their own "labor by vocation" (2019). From play to play, the dramaturg makes a human the centre of his attention. For this, in his play "Where is the Truth?" the author introduces the discussion about the human's place in the universe, their mission and the ability to make difference.

In all the works of the play-writer the words are granted an acting power. However, employing them for the effect of stagey, O. Chyrkov has to combine deep philosophical contemplations with spectacular scenes. Dancing, poisoning, etc. are referred to such kind of scenes.

Thus, the macrotheme of O. Chyrkov's plays is the possibility of the truth, the truth in search of harmony. The content of the plays is aimed to highly intellectual readers and audience. Another feature is the specific depicture of a person. The subject is not their fate, but their role in society or attitudes towards social defects which constitute one of the conflicting ideas. When depicting certain social phenomena, the playwriter always establishes cause-and-effect relationships.

The specific feature of an epic drama is a strong presence of the author. O. Chyrkov's view in the plays is clearly outlined in occasional lengthy stage directions, intertextual inclusions, motionpicture images that appear in parallel with the performance, in the musical accompaniment, etc.

Another prominent phenomenon in the contemporary literary process is the drama works by H. Shton, who is famous for the two books of plays, the staged performance at the Dnipro 
National Academic Ukrainian Music and Drama Theatre named after T. Shevchenko, the winning of the International Multi-Art Contest "Word's Coronation". In his private interviews, the playwriter and literary scholar has repeatedly mentioned that his drama is intellectual. From a scientific point of view, the similar opinion has been expressed by L. Krasnova. Another literary critic, L. Moroz maintains the fact of contemporary Ukrainian intellectual and philosophical drama appearance. And although "some play-writers make attempts (mostly successfully) to grow up to the level of philosophizing," they still "sometimes go astray to myth-making." H. Shton's drama works are distinguished by philosophical discussions "from the first line to the last one, even in such worldly matters as heart-to-heart talks." The confrontation occurs around not only "contemporary, quite unexpected" but also eternal issues: "life and death, freedom and imprisonment, truth and lie, good and evil" (Moroz, 2012).

In her speech at the meeting of the Creative Association of Critics of the Kyiv organization of the Ukraine's National Union of Writers, L. Moroz provided the details of her observations and claimed that there is no traditional external conflict in the works of the play-writer, whereas analytical consideration is aimed at selfunderstanding and understanding of others, as well as contemplation of "their place and selfperception in the universe..." (Kononchuk, 2013). We have analyzed all the achievements of the play-writer and obtained the following systematic observations.

Among the author's genre definitions there is a noticeable synthesis of dramatic genres with epic (essay, saga) and lyric (elegy, cantus, and idyll) ones. The eloquent is the choice of genre for the play "At the Fire of the Gods" which is a cantus, a song for a three-part ensemble. So it is no surprise that we see three actors in the play Oleksa, Vasyl and Artemis - whose words sound like distinctive voices in the ensemble. The openness of the play-writer to intertextuality is testified by making a collage a genre with a polyphonic structure. Most notably, this polyphony sounds in the song "The Sorrows of Love." The range of genres of H. Shton's plays is pretty diverse and encompasses parables, social and moralizing plays, as well as biographical ones.

Careful reading of the numerous interviews with H. Shton explicitly indicates how important for him is the portraying of characters. The playwriter studies human characters not in an abstract way, but specifically paying attention to the representatives of all social sectors: politicians, physicians, educators, scientists, etc. Putting words in his characters' mouths, H. Shton sought to achieve speech characterology, which implies "not an intelligent or foolish talk, but the characterology, where each word means a human" (2012).

Ideologically, all the drama works by H. Shton are aimed at finding a man's own nature. Everyone has their own way, but it depends on the type of everyday activity. No wonder, the owner of several gas stations and a car dealership Stepan Mykhailovych ("Christmas Feasting") metaphorically said: "It is a very complicated matter when life is an empty vehicle. Sooner or later that empty vehicle begins to rattle. And all this happens inside, along with thoughts about success, respectability..." (Shton, 2013: 26). At the same time H. Shton breaks the established pattern of materialization of all values for business people. No wonder, Stepan Mykhailovych ("Christmas Feasting") claims the family as the highest value.

The play-writer depicts not only all social classes but also the cyclical nature of human life: "There is a frontier of forty-seven. Then the indifferent seventy. And after, either a collapse or a power outage" (Shton, 2013: 315). In addition, H. Shton, in order to reveal the essence of the human personality as such ("life outside of life"), creates situations where the thinking of characters is shown the best way: moves them to the new conditions, arranges meetings in a critical state, when there is a need to rethink the life or return "to being one of mother's". The play-writer outlines several ways of self-understanding, but the most effective is the appeal to the past. Therefore, the key in the character formation plane is that the recipients of H. Shton's plays cannot follow the character formation process, but are able to witness the process of conscious self-reflection.

Thus, everything in each play of H. Shton - from content to form - is the evidence of intellectuality of the author's drama works: ambiguous names of plays, synthetic drama genres, the author's symbolic explanations, philosophical content of the plays, intertextual inclusions, multifunctional remarks, macro-plot of all drama works. In addition, there is a strong focus on the character formation, since all the characters are in a state of self-reflection; whereas an inner conflict of the 
plays and a distinct nationalist stream merely serve to underline this intellectuality.

The genres which can be referred to intellectual drama are also biographical drama and family (social) drama. Thereby we can mention $\mathrm{H}$. Shton's play "His Excellency Poet", which premiered on March 16, 2014, (stage director Anatoly Kantsedailo, Honored Artist of Ukraine). This is the first theatrical performance of the play on the professional stage, although its stage life began earlier, in January 2014, at the "Pechersk", Center for Art and Technical Creativity (Kyiv).

The plot of the play falls on the time when the main character's life, Shevchenko, "seemed to be improving": "Having become an artist, my poems are read voraciously even though I do not yet understand who I am - a painter or a poet? Maybe both together, because poems are inspired by beautiful painting; and the painting is beautiful when the soul is singing..." The author along with the director have managed to present to their recipient the poet's soul rather than his physical reality.

A literary analysis of "His Excellency Poet" makes it possible to see the play's internal conflict, which is its core, and it provides a cohesive integrity. Undoubtedly, the main character of the play is Shevchenko, but the reader's attention is constantly shifting to the image of Literature, which "cannot tolerate slavery". All these features refer the play to intellectual drama genre, which is difficult for staging.

According to the author's script, the first scene of the first act begins when Zabila looks at "ancient porcelain bowls with duck, sauerkraut, donuts with pork rinds, corned beef, and a large bottle with mead, several decanters with tinctures, plum brandy and state liqueur". In the theatrical performance, though, the audience is exposed to the table laid with mostly artificial food and dishes, which helps to shift the emphasis from the external circumstances to the content of the lines.

The house set on the stage is outlined with the frame-walls divided into the large rectangular windows opened by the leading characters. At that, the light accents are focused on a newly opened window, as on the back of each shutter the audience is shown one of the painting masterpieces by Shevchenko (his self-portraits from the different periods of life, images of Oksana, sketches from the manuscripts, etc.). These frame-walls are used as a main decorative feature throughout the play, and in the closing scene they are supplemented with the strongly illuminated hollow backdrop middle frame, where Shevchenko takes himself off.

We can also point out that the contemporary Ukrainian family drama is experiencing a successful stage life. Here we are referring to the play "The Girl with the Teddy Bear, or Under Age" (libretto by Pavlo Arie). This play is successfully performed at the Kiev Academic Drama Theater on Podil (directed by Stas Zhyrkov). The director's opinion is that the theater should not serve the literature. Therefore, the director, working with $\mathrm{P}$. Arie on the novel by Victor Domontovych, was free to experiment with sound, light, etc. All the director's artistic findings worked to create an emotional and intellectual impact on the recipient.

In this regard, it is worth mentioning the play by I. Koval, "Pagan Saints", which is known to theater critics as "The Lion and the Lioness." Referring to the play, V. Grytsuk, the theatrical expert, states the following:

In this play, the plot as a series of events with the action development up to a culminating point does not exist, whereas the director has managed to build a cycle composition comprising different variants of the one conflict. This compositional cycle along with the comically repeated tragic situations in the play associate with a number of 'antiplays' of absurd type. Here the conflict grows not from a dramatic structure, but from the naturally opposite worldviews of Man and Woman, who bombard each other with the variations of proves every day/ (Koval, 2005: 12) The play "Station..." has several theatrical performances - in the Theater "aBRaKaDaBRa", the Theater Center NaUKMA "Pasika", the Dnipro Theater "Masky", the Lviv Theater "My", the Kyiv Theater "MIST" (Doshch, 2012: 148). According to the scientific classification of genres, this play can be referred to as a drama of ideas.

Three characters - Tania, Olia and Ira - are the three models of attitude towards life values. Olga always takes care of comfort. The tangible is the girl's number one concern: she believes she can solve any problem with money. Obsession with material wealth determines Olga' attitude not only to the environment but also to people. She explicitly violates conventional ethical standards while communicating with people, especially when addressing them. Olga dates with men only to satisfy her own physiological needs. And only as the plot unfolds, we understand that Olga's 
true values are the harmonious family relationships achieved after a baby birth.

Tatiana's self-assessment of her own life makes it clear that she experiences lack of novelty and harmony. Irina also prefers material values. The play-writer attributes this to the lack of desire to live for the sake of another.

Realizing the purpose of the Station - to restore the ability to have sincere desires, dreams of living for the sake of others - the girls display different attitudes to the leaving. Irina has doubts about wishing to leave the Station. Tanya has lost her faith in the ability to leave the Station and admitted that this world had captivated her. She feels as if she has become its prisoner because without any effort she has gained peace and comfort, losing her soul. Olia has remembered her childhood wish. She not only realizes that the desire to live for the sake of someone is impossible without the ability to sacrifice, but also decides to live for the sake of the child; therefore, she gets the opportunity to fly away from the Station.

Thus, raising the basic philosophical conflict between internal desires of comfort and the ability to live and do good for the surrounding community (family, loved ones) - Oleksandr Viter puts it in as an internal conflict, focusing on the characters for its highlighting.

Sashko Ushkalov, Artem Vyshnevskyi in the interview repeatedly emphasize the importance of such writing features of play-writers as attentiveness and observation, thoughtfulness, conscious attitude to the creative process. As a result, the pinnacle of the artistic skill is the ability to express an eternal idea through the new material. The book "ESC. Seven absurdist plays" is seen by Sashko Ushkalov as experimental, as a response to predictable literature. Consequently, at first glance, decoding is required for absurdities, built-up casualties, etc. The name itself hints at the phenomenon of human escape from the negative impact of the surrounding reality into the world of illusions.

Sashko Ushkalov's plays are full of symbols. For instance, in the head of Alain the Bat, appear salamanders. For understanding the role of this character, one should know that the bat is a symbol of treachery and evil, and salamanders symbolize the fight against carnal pleasures. The being of a human is volatile and unstable, which is symbolized in sand that appears in Alain's dream. In the battle between evil and good, the latter always wins. That is why in his dream Alain sees cherries symbolizing good deeds.

In the drama of absurd, the internal conflict is clearly outlined. One of its kind is the selfidentification conflict ("Oecumene"). The semantics of the name - "inhabited world" gives rise to the awareness of the need to know one's own world. The image of a traveling Tortoise extends the decoded value. Everyone wants to exercise their right to go beyond their oecumene.

According to the play-writer, life-saving power given to people is their ability to dream and hear one another. To find freedom, one must know God. That is why in the play "Susie, the Dwarf, and others (the story of one healing)" "in the middle of the stage there is a road sign: a blue circle with the inscription 'God $\uparrow 50 \mathrm{~m}$ '" (Ushkalov, 2006: 7), and the angels are symbolized in the images of penguins. At first glance, such parallels seem unrelated, but the most common features of the angels are exclusivity and perfection manifested in their purpose and behavior. The similar features are attributed to penguins since they are the only strong, fast birds that do not fly but walk in a standing position and are a symbol of freedom and troubleshooting.

A holistic view of contemporary absurdist drama will help to analyze A. Vyshnevsky's play "Riznytsia", which the author defines as a "drama of the absurd." The word "riznytsia" in Ukrainian has many unrelated meanings, such as "the difference", "the subtraction", "the slaughterhouse"; that is why the title of the play is ambiguous. All three notions are realized in the play. Thus, one of the characters, Colorblind, verbally opposes other characters - Green and Brown. This "otherwise-minded" claims that the difference does not exist in general. Green sees the difference as a result of subtraction: "If you subtract green from the brown, the result will be, scary to say, red" (Vyshnevsky, 2006: 16), which is nothing but a hint at the domination of totalitarianism, the predominance of which is inevitable when power confronts the people. The character Difference defends its existence: "I am the difference. I work in a meat processing plant and cut off heads of various cattle" (Vyshnevsky, 2006: 24). This is how totalitarian power got rid of those who wanted to be different. This interpretation is confirmed by the symbolism of color. Brown is the color of decay (the power that performs the decay), and green, despite the meaning of fertility (the potential of the people) 
is interpreted as suppression, indifference (the state people experience under the pressure of totalitarian authority). So, it is significant that Green is an ambivalent color that belongs to the group of warm colors, cool colors and sevencolor spectrum.

Green means positive features. This is embedded in his self-estimation:

You know, my soul hurts not for myself personally. For the whole world. Our people lack some sincerity, you know, something genuine. Everyone plays roles, carries out useless experiments, constantly tries to prove something to each other, to put one another in their places ... How do they know people's places?! (Vyshnevsky, 2006: 23)

Brown's words are contrasting, empty and meaningless. The monotony, the colorlessness of life is what Colorblind is talking about. He is keen on seeking the meaning of life: "How to live in such a world? How? Monotony is everywhere. Everything is the same. No difference... How to live? How?" (Vyshnevsky, 2006: 14). These views of Colorblind are what set him apart from his environment.

The fear for his family makes Green conceal his true nature. All characters are defeated, as in order to withstand the totalitarian pressure, a person should be deprived of fear and overcome the inability to see differences.

Thus, the specific feature of an artistic conflict of an absurd play lies in the abundance of symbolistic semantics, binary, prevalence of internal form expression and lack of plot motivation.

Intellectualization of Contemporary Ukrainian Theater

In the contemporary dramatic art there is a place for the action theater, and its mission is to provoke actors to conduct experiments with the audience. In this regard, it is worth mentioning the Theater "Territory" (the theatre group of Dmytro Levitsky, Khmelnytskyi City). For instance, this theater's troup showed up on the summer beach in winter clothes, having made the audience to open up to perception. As a result, such experiments stimulate the actors themselves for a deep introspection. Another experiment was staged in Lviv by Sashko Brahma as part of the "Drabyna" festival. The play was staged in a cafe, bringing together both its visitors and the audience. Another experiment took place in
Kherson's bathhouse. There was performed the play by Yevhen Markovskyi, the winner of the festival "Week of the Modern Play". In order to achieve the effect of a bathhouse according to the original text, the stage director Andrii May, in addition to the required setting, requested from the audience to follow the dress code: to wear swimwear and slippers. According to the author of the play, this was the best stage performance ever. In general, the experimental nature of performances is the tendency reflected in the work of stage directors.

"The stage production work on contemporary drama is completely opposite to the plays in the genre of psychological realism (or 'traditional' plays) which were conventional for Ukrainian audience of the 20th century. The theater plays of today are characterized by rejection of verisimilitude, the traditions of psychological realism, the presence of natural elements and archetypes on the stage, orientation to the metaphysical essence of what is happening on the stage. Particular feature is the abstinence from emotional loading of events and characters, which, accordingly, requires considerable effort from the audience to interpret what they see. The dominant feature of these performances is the mixture of various styles, i.e. going beyond the boundaries of stylistics, space and acting. The contemporary stage actively uses elements of cinema, video, art performance, contemporary music and literature, as well as contemporary dance. All of these components require different specialty in the work of an actor" (Tuzhyna 2011: 114).

Within the walls of the Kyiv Academic Theater Arts Workshop "Suziria", the play "All About Love" (by the stage director People's Artist of Ukraine Oleksii Kuzhelnyi) had its first performance. The stage director named his work a tesseract based on the play "On Own Way" by Oleksandr Oles. The intellectual message lies in the combination of the traditional and the extraordinary, since O. Kuzhelnyi created a mix of literary material with pantomime, video and animation. The specific feature of the performance is that the text of Oleksandr Oles is displayed on the screen with the letters moving in different ways. In the interview with Lilia Bondarchuk, the director opened up his artistic priorities: "For us, the creators of the play, it is extremely important to make the audience read the text as such and at the same time to comprehend: behind the words and letters there is something more meaningful, something like another reality" (Kuzhelnyi, 2009: 8). 
When reading a work of art, the imagination of a reader creates some visions and, thus, a new reality opens, which means emergence of new senses. Such process is quite complicated, as when one perceives a work of art, it appeals to memory, experience, feelings, knowledge, etc. Experiencing the play, the audience has the opportunity to see the director's suggested interpretation of the text. Also, this performance is unique due to the fact that the audience becomes a participant of the performance. This is facilitated by a unique stage solution: the bed (fabric stretched over a metal frame) is placed front to the audience. "The audience is able to imagine themselves above it. As a result, the angle of their vision changes and new content emerges (they feel either as if on a plane watching this bed or as if flying like a bird)" (Kuzhelnyi, 2009: 8).

Theater critics have noted the success of A. Kantsedailo's staging of A. Havrosh's play "Romeo and Jasmine" at the Dnipro Theater named after T. Shevchenko, of O. Shaparenko's staging of A. Mykolaichuk's play "Wild Honey in the Year of the Black Rooster" at the National Center for Theater Arts named after L. Kurbas, of O. Myroshnychenko's staging of O. Viter's play "Love Hunting Season" at the Kyiv Theater "MIST", of V. Golovko's staging of Neda Nezhdana's play "Agreement with the Angel" at the "Academic Palace" (Chernivtsi City). The mask principle, the existence of several worlds discerned by their scenic location, plasticity and costumes, the complicated composition build-up, the ambiguous finale along with the colour and sound effects all together are what accentuates the intellectual flow of the performances.

\section{Conclusions}

In spite of the presence in contemporary scientific works, the terms 'intellectual drama' and 'intellectual theater' have blurred boundaries. In these days, play-writers or stage directors position their works as intellectual. Therefore there is an urgent need for understanding, theoretically and on the material of specific artistic actualization, which works are positioned as intellectual. The category of genre was taken as the basis for material structuring. Such approach made it possible to understand what genres are productive for intellectualization.

The priority was given to the analysis of theoretical works. As a result, the characteristic features of intellectualization were emphasized.
They are a state of self-awareness of a character, the prevalence of intellectual themes, and the programmability of dialogues verged upon their content, etc.

The long-term study of the contemporary Ukrainian drama provides a basis for stating that the drama-parable, the intellectual and philosophical drama, the biographical drama, the drama of the absurd are referred to the genres of the intellectual drama actualization.

In addition to the characteristic features listed above, there used inter-textual and inter-medial elements, symbols, aphoristic speech of characters, and speech characterology. Escalation of conflict is emphasized by means of special stage features (a moving platform, specific color or sound, etc.). During the performances, stage directors try to shift the focus from external factors to the inner world of characters. The conflict of self-identification is among the variety of inner conflicts presented in plays.

Regardless of the genre determined by a writer for a work, no matter what generation an author identifies himself with, the play-writers are common in the importance of keeping eye on the today's world. But this does not condition the realism of the content of scripts or when performed on the stage. The synthesis of styles, arts, and acting provocations is dominated on the stage. The most important thing is to encourage the audience to think.

\section{Bibliographic references}

Brockett, O. G., and Hildy, F.J. (2014). History of the theatre. Pearson.

Chyrkov, O. (2019). Time and times: plays. Zhytomyr: O. Jevenok.

Comte, A. (1858). The Catechism of Positive Religion. London: Harvard College Library.

Doshch, I. (2012). In search of freedom: a new feeling of reality in theatre diagnosis. An overview of contemporary playwrights. Dnipro, 3, 146-149. Retrieved from http://www.dniproukr.com.ua/rubrik_description-21339.html

Esslin, M. (2001). The Theatre of the Absurd. New York: Vintage Books.

Kononchuk, T. (ed.). (2013, April 04). Critics about theatre's drama. Ukrainian literary newspaper, p. 14. Retrieved from https://litgazeta.com.ua/articles/krytyky-prodramu-teatru-2/ 
Koval, I. (2005). Pagan Saints. Marinated Aristocrat: Plays. Kyiv: Fakt. ISBN 966-359026-2.

Kuzhelnyi, O. (2009). "More important than text...". Kino-Teatr, 4, 8-9. Retrieved from https://elib.nlu.org.ua/view.html?\&id=3085

Moroz, L. (2012). Nostalgia for intellectual communication. Kino-Teatr, 6 (104), 45. Retrieved from https://elib.nlu.org.ua/view.html?\&id=2977

Pavis, P. (1998). Dictionary of the theatre: terms, concepts, and analysis. Toronto and Buffalo: University of Toronto Press.

Pavis, P. (2012). Semiology after semiology. Theatralia, 15(2), 37-49.

Shton, H. (2012, October 19). "I write the way I write: no cry and buskins, no escaping into the shadow of the classics and no right to make a mistake." Mykhailo Sydorzhevskii's conversation with Hryhorii Shton. Ukrainian literary newspaper, p. 6. Retrieved from https://litgazeta.com.ua/interviews/grygorij- shton-pyshu-tak-yak-pyshu-bez-lementu-ikoturniv-bez-vtech-u-tin-klasyky-i-bez-pravana-pomylku/

Shton, H. (2013). Plays. Book second. Kryvyi Rih: Vydavnychyi dim. ISBN 978-966-177-1603.

Tuzhyna, V. (2011). Like ships in the sea. Dnipro, 2, 114-115. Retrieved from http://www.dnipro-

ukr.com.ua/rubrik_description-5293.html

Ushkalov, S. (2006). ESC: seven absurd plays. Kharkiv: Maidan. ISBN 966-372-024-7.

Vyshnevsky, A. (2006). Patchwork breed: plays. Rivne: Azalia.

White, J. P. (1903, February 1). The pandarism of the intellectual drama. The New York Times. Williams, H. (1920). Outlines of modern English literature, 1890-1914. London: Sidgwick \& Jackson.

Yermolenko, V. (2018). Flowing ideologies: Ideas and politics in Europe, 19th to 20th century. Kyiv: Spirit and Letter. 